\title{
A FORMAÇÃO DE PROFESSORES PARA A DIFERENÇA: UM ESTUDO SOBRE OS CURSOS DE LICENCIATURA DA UNICAMP E SUAS IMPLICAÇÕES EM EDUCAÇÃO INCLUSIVA
}

\author{
Bárbara Ceotto Souza*, Maria Teresa Eglér Mantoan
}

\begin{abstract}
Resumo
Um dos obstáculos para a concretização da educação inclusiva é a formação inicial dos alunos das Licenciaturas, futuros professores dos Anos Finais do Ensino Fundamental e Médio, cujos currículos não dão conta do entendimento da inclusão em seu sentido amplo e restrito e das práticas pedagógicas alinhadas a essa perspectiva educacional. Tais alunos se sentem despreparados para ensinar diante das diferenças dos alunos em geral e, principalmente, do público alvo da Educação Especial. A intenção desta pesquisa foi conhecer as possíveis razões pelas quais esse despreparo persiste, especificamente na UNICAMP. O estudo revelou uma incoerência entre a formação oferecida à esses alunos e a legislação vigente, os currículos das Licenciaturas e a abordagem facultativa dos professores sobre o tema.
\end{abstract}

\section{Palavras-chave:}

Inclusão, Formação de Professores, Licenciaturas

\section{Introdução}

A história brasileira em relação à educação inclusiva partiu de legislações que propiciavam o atendimento de alunos com deficiência em espaços à parte e excludentes. Os profissionais que neles atuavam possuíam igualmente formação e habilitação específicas para esse público alvo. Em 2008, a Política Nacional de Educação Especial na Perspectiva da Educação Inclusiva ${ }^{1}$ (PNEEPEI) introduziu na educação brasileira a obrigatoriedade da escolarização desses alunos no ensino comum, trazendo a necessidade de se incluir na formação de professores temas relacionados à inclusão escolar e aos novos serviços da Educação Especial. Entretanto, apesar das conquistas expressas na legislação vigente no país desde a Constituição de 1988 até o marco da PNEEPEI, esse preceito legal ainda encontra diversos obstáculos a serem transpostos para que a inclusão seja de fato implementada nas escolas. O obstáculo estudado nesta pesquisa é a formação inicial dos professores do Ensino Fundamental II e Médio. A investigação recai sobre os Projetos Políticos Pedagógicos das Licenciaturas, as disciplinas obrigatórias oferecidas pela Faculdade de Educação para esses alunos e sobre os professores responsáveis por elas.

\section{Resultados e Discussão}

A análise dos Projetos Políticos Pedagógicos dos cursos de Licenciaturas da UNICAMP disponibilizados eletronicamente (Matemática, Ciências Biológicas, Química, Sociologia, Letras, Geografia, História, Educação Física, Filosofia, Física, Física e Química) revelou que a grande maioria dos cursos não possui nenhuma disciplina com ementa ou tópicos voltados para discussão da Educação Especial e seus alunos, com exceção da disciplina de LIBRAS (Língua Brasileira de Sinais). Dentre as três disciplinas teóricas obrigatórias desses cursos na Faculdade de Educação (Escola e Cultura, Psicologia e Educação, Política Educacional: Organização da Educação Brasileira), nenhuma têm ementa que remete à inclusão de alunos público alvo da Educação Especial. A partir das entrevistas realizadas com alguns dos professores responsáveis por essas três disciplinas e com a coordenadora de Licenciaturas da
Faculdade de Educação, apuramos que a temática da inclusão de alunos dessa modalidade de ensino só é abordada de forma facultativa pelos professores. No entanto, pelo estudo do histórico das legislações que regem a formação de professores no Ensino Superior no Brasil, constatamos que a ampla maioria das Licenciaturas da UNICAMP ainda não respeitam as atuais Diretrizes Curriculares Complementares para a Formação de Docentes para a Educação Básica nos Cursos de Graduação de Pedagogia, Normal Superior e Licenciaturas oferecidos pelos estabelecimentos de ensino superior vinculados ao sistema estadual de SP (2017) ao não assegurar aos futuros professores dos anos finais do Ensino Fundamental e Médio os "conhecimentos dos marcos legais, conceitos básicos, propostas e projetos curriculares de inclusão para o atendimento de alunos com deficiência" (p.3).

\section{Conclusões}

A ausência de abordagem dos conteúdos referentes à educação inclusiva a partir da não obrigatoriedade deste tema no currículo das Licenciaturas contraria a legislação vigente e contribui para o despreparo dos futuros professores frente à diferença de todos os alunos. Não são os especialistas nem os métodos especiais de ensino escolar que garantem a inclusão real de todos os alunos na escola regular, mas sim a formação dos professores para trabalhar com a diferença em si (Deleuze, 2008) ${ }^{3}$ nas escolas. $\mathrm{O}$ tratamento obrigatório de questões relativas à inclusão do público alvo da Educação Especial na formação inicial dos professores possibilitaria a eliminação de grande parte dos obstáculos que se interpõem entre a escola regular e esses alunos.

\section{Agradecimentos}

Ao PIBIC e ao Conselho Nacional de Desenvolvimento Científico e Tecnológico (CNPq) pela bolsa concedida.

${ }^{1}$ BRASIL. Ministério da Educação. Política Nacional de Educação Especial na perspectiva da Educação Inclusiva. Brasília: MEC/SEESP, 2008.

${ }^{2}$ BRASIL. Conselho Estadual de Educação. Deliberação N ${ }^{\circ} 154 / 2017$. Dispõe sobre alteração da Deliberação CEE nº 111/2012.

${ }^{3}$ DELEUZE, Gilles. Conversações. 1.ed. São Paulo, SP: Ed.34, 2008. 